\title{
Bioaccumulation of Cadmium by Pseudomonas $S p$. Isolated from Metal Polluted Industrial Region
}

\author{
M. P. Krishna ${ }^{1}$, Rinoy Varghese ${ }^{1}$, Arun V. Babu ${ }^{1}$ and \\ A. A. Mohamed Hatha ${ }^{2}$ \\ ${ }^{1}$ School of Environmental Sciences, Mahatma Gandhi University, Kottayam, Kerala. \\ ${ }^{2}$ Department of Marine Biology, Microbiology and Biochemistry, Cochin University of Science and Technology, \\ Cochin, Kerala.
}

cross $^{\text {ref }}$ http://dx.doi.org/10.5755/j01.erem.61.3.1268

(received in February, 2012, accepted in September, 2012)

\begin{abstract}
In the study bacterial strains were isolated from soil, sediment and water samples taken from the metal contaminated industrial area, and heavy metal resistance and bioaccumulation potential of the isolates were investigated. Cadmium analysis of the samples revealed that $\mathrm{Cd}$ concentration varied from $2.31 \mu \mathrm{g} \mathrm{L}^{-1}$ to 8.96 $\mu \mathrm{g} \mathrm{L}^{-1}$ in water, from $0.55 \mu \mathrm{g} \mathrm{g}^{-1}$ to $25.44 \mu \mathrm{g} \mathrm{g}^{-1}$ in soil and from $0.45 \mu \mathrm{g} \mathrm{g}^{-1}$ to $22.90 \mu \mathrm{g} \mathrm{g}^{-1}$ in sediment. Cadmium resistance studies of the bacterial isolates showed that out of 164 collected isolates the majority demonstrated low resistance $(<500 \mu \mathrm{g} / \mathrm{ml})$, while the rest showed high resistance of $>1500 \mu \mathrm{g} / \mathrm{ml}$. 10 bacterial genera were recorded from soil, 11 from water and only 5 bacterial genera from sediment samples. Bacillus, Pseudomonas and Enterobacter were found in soil, sediment and water samples. Results of the cadmium removal study revealed that with an increase in time the biomass of selected Pseudomonas sp. increased. Correspondingly, with an increase in biomass the cadmium bioaccumulation also increased. Relatively, an increased removal of cadmium was observed in the first day of the experiment. About $40 \%$ of cadmium decreased in an experimental flask, while in the control flasks reduction was only $5 \%$ till the end of the experiment $(74 \mathrm{hr})$. Comparatively, cadmium showed higher reduction at $\mathrm{pH}$ 7. The results allowed to conclude that the selected bacterial isolates possessed a potential for bioaccumulation activity and thus appeared to be an appropriate nominee for bioremediation processes.
\end{abstract}

Keywords: Industrial area, metal pollution, cadmium, metal resistance, Pseudomonas, bioaccumulation.

\section{Introduction}

Manufacture of heavy metal has greatly increased since the industrial revolution (Ayres 1992). Heavy metal represents a significant hazard for the human health and the ecosystem (Boopathy 2000), and it usually forms compounds that can be toxic, carcinogenic or mutagenic even at very low concentrations (Ruiz-Manriquez et al. 1997). Some heavy metal, including iron, zinc, copper and manganese, is micronutrient used in the redox processes, in regulation of osmotic pressure as enzyme cofactor, and it has special importance to maintenance of the protein structure (Vallee and Auld 1990). However, even essential metals, for example zinc and copper, are toxic at their elevated level. On the other hand, metals, including lead, cadmium etc., do not play any known physiological role and are, in fact, toxic. Scientific literature indicates that cadmium is one of heavy metal that has been recognized as a potent human toxin with reports of many diseases. The kidney, especially the renal tract, is a critical organ of intoxication after the exposure to cadmium.

Conventional methods of removing metals such as precipitation, oxidation or reduction have been commonly used to remove heavy metal from industrial waste water. They are ineffective or expensive, though. Substitute methods of metal removal and revival based on biological resources have been considered. Certain types of microbial biomass can keep comparatively high quantities of metal by means of passive processes known as biosorption (Raras 1995). Such processes are of industrial interest, since the removal of potentially 
hazardous heavy metal from industrial effluents by microbial biomass can lead to detoxification and also to recovery of valuable elements (Brierley et al. 1985). The use of bacterial biomass for the metal removal process of effluents is a viewpoint suggested by many researchers dealing with metal-bacteria interactions (Gadd 1993).

The aim of the present research was to isolate and characterize bacteria from soil, sediment and water of the Eloor-Edayar industrial zone, Kerala, South India, to study the cadmium resistance pattern, the $\mathrm{Cd}$ bioaccumulation potential of the selected bacteria and $\mathrm{Cd}$ contamination in that industrial area.

\section{Materials and Methods}

Study area: the Eloor-Edayar industrial area the largest industrial belts of Kerala are parts of Ernakulam districts of Kerala, south India, located in $76^{\circ} 17$ ' 32.9" - $076^{\circ} 18^{\prime} 31.8^{\prime \prime}$ E longitudes and $10^{\circ}$ 04' 51.6" - $10^{\circ} 04^{\prime} 38^{\prime \prime} \mathrm{N}$ latitudes, and it is a chronically polluted area, one of the biggest exporting centers of fertilizers and chemicals. Eloor is a of FACT, TCC, IRE, HIL and many other small and big industries situated on the lower flood plains of the river Periyar and it is an island of $14.21 \mathrm{~km}^{2}$ formed between two distributaries of the Periyar.

Collection of Samples: Soil, sediment and water samples were collected from abandoned paddy fields, canals and river of the selected industrial area. Totally, seven sampling sites were identified and from each of them soil, sediment and water samples were collected. Soil samples were collected at the depth of 15 to $20 \mathrm{~cm}$ from the surface after removing the top layer. For each of the sampling sites, sub-samples of soil were collected from different locations, pooled together and homogenized in a way to obtain a representative sample. Samples were collected by means of spades which were thoroughly cleaned and disinfected between sampling to prevent crosscontamination. Sediment samples were collected using a Grab sampler and inserted into sterilized plastic bags. Water samples were collected using sterilized plastic bottles. Soil, sediment and water samples were transferred to an ice box and transported to the laboratory.

Cadmium analysis: Cadmium in water was determined with Anodic Stripping Voltammetry (797 VA Computrace, Metrohm) after acid digestion of the sample as per the method described in APHA 1998. For sediment and soil, the samples were firstly air dried and then ground to fine powder using a pestle and mortar. Then the samples were separated into two different granulometric fractions, $<200 \mu \mathrm{m}$ and $<$ $63 \mu \mathrm{m}$, using stainless steel sieves. An aliquot of $0.25 \mathrm{~g}$ of powdered sediment of $<63 \mu \mathrm{m}$ was digested with Selectipur Nitric acid using a microwave digester (MARS X PRESS, CEM, USA) as per USEPA 3051a for heavy metal (Kingston \& Jassie 1988; Kingston et al. 1997). The digested solution was filtered through Whatman No: 1 filter paper and finally the volume amounted to $25 \mathrm{ml}$ with ultrapure water (Elga ultrapure water system UK). Cadmium was then determined by Voltammetric Trace Metal Analyzer797 VA Computrace, Metrohm (Ireland- Ripert et al. 1982; Lo \& Lee. 1994).

Isolation and identification of bacteria: Isolation and enumeration of bacteria were carried out by the standard serial dilution plate technique. Serially diluted samples were sown on nutrient agar and incubated at $37^{\circ} \mathrm{C}$ for $24-48 \mathrm{hr}$. Bacterial colonies from nutrient agar were isolated, purified and maintained as pure culture for a further study. Bacterial isolates maintained as pure culture on nutrient agar were characterized and identified up to a genus level by morphological tests as per Bergey's Manual of Determinative Bacteriology: $9^{\text {th }}$ edition (Holt et al. 1994) and $8^{\text {th }}$ edition (Buchanan and Gibbons 1974). Morphological tests carried out for identification of the isolates were Gram's staining, cell shape and arrangement, pigment production, $\mathrm{O} / \mathrm{F}$ glucose tests, Endospore staining, Motility, Catalase, Oxidase etc.

Bacterial cadmium resistance test: Resistance of the bacterial isolates to varying concentrations of cadmium was determined by an agar dilution method (Luli et al. 1983). Fresh overnight cultures of the isolates grown in peptone water were aseptically inoculated into the nutrient agar plates which were supplemented with increasing concentrations of cadmium metal ions $\left(500 \mu \mathrm{g} \mathrm{ml}^{-1}\right.$ to $\left.1.5 \mathrm{mg} \mathrm{ml}^{-1}\right)$. The plates were incubated at the room temperature and observed for bacterial growth. The lowest concentration of cadmium at which no growth occurred when compared to the control plates was considered as the Minimal Inhibitory Concentration (MIC). Metal salt was added to the medium after autoclaving and cooling to $45-50^{\circ} \mathrm{C}$, from the filter sterilized stock solutions. Metal salt used for that study was Cadmium nitrate $\left(\mathrm{Cd}\left(\mathrm{NO}_{3}\right)_{2} \cdot 4 \mathrm{H}_{2} \mathrm{O}\right)$.

Bioaccumulation of Cadmium: The bacterium (strain TCC50) growing in the largest cadmium concentration was selected for the study and it was identified as Pseudomonas. The bioaccumulation method at different $\mathrm{pH}$ (5, 7 and 9) with living bacterial cells was used for cadmium removal. To study heavy metal removal with live cells, nutrient broth amended with initial concentration of cadmium (20 $\mathrm{mg} \mathrm{L}^{-1}$ ) was inoculated from overnight grown cultures of the selected bacterial isolates. The inoculated flasks were incubated in shaking conditions at the room temperature for $72 \mathrm{hr}$. An aliquot of $5 \mathrm{~mL}$ sample was taken daily (with a $24 \mathrm{hr}$ interval) from each flask. The control flasks without bacterial biomass were running simultaneously with the experiment flasks. The samples were centrifuged to remove suspended biomass, and the supernatant heavy metal concentration was determined. 


\section{Results}

A total of 18 bacterial genera were recorded from the selected industrial area. 10 bacterial genera were represented from soil, 11 from water and only 5 were recorded from sediment samples (Table 2).

Table 1. Heavy metal concentration in soil, water and sediment samples from the selected industrial area

\begin{tabular}{|l|c|c|c||}
\hline \multirow{2}{*}{$\begin{array}{l}\text { Sample } \\
\text { Name }\end{array}$} & \multicolumn{3}{|c|}{ Metal concentration } \\
\cline { 2 - 4 } & $\begin{array}{c}\text { Soil }\left(\mu \mathrm{g} \mathrm{g}^{-}\right. \\
1^{-}\end{array}$ & $\begin{array}{l}\text { Water }\left(\mu \mathrm{g} \mathrm{L}^{-}\right. \\
1^{\prime}\end{array}$ & $\begin{array}{c}\text { Sediment } \\
\left(\mu \mathrm{g} \mathrm{g}^{-1}\right)\end{array}$ \\
\hline TCC & 1.22 & 3.465 & 0.45 \\
\hline BPM & 25.44 & 5.774 & 21.48 \\
\hline KDM & 0.55 & 2.316 & 2.78 \\
\hline BR & 2.47 & $\mathrm{nd}$ & 1.72 \\
\hline WMH & 1.34 & $\mathrm{nd}$ & 0.60 \\
\hline RFH & $\mathrm{nd}$ & 5.086 & 22.90 \\
\hline WB & 5.95 & 8.962 & 12.73 \\
\hline Mean/SD & $5.28 / 9.1$ & $3.6 / 3.2$ & $8.95 / 9.9$ \\
\hline
\end{tabular}

Wetland near Binanipuram (WB), Wetland near Merchaam and HIL (WMH), Kuzhikandam canal (KDM), Canal near Binanipuram (BPM), the Binananipuram river (BR), the Pathalam bund river (TCC), River near FACT and HIL (RFH), Standard deviation (SD).

Bacillus, Pseudomonas and Enterobacter were found in soil, sediment and water samples. Cadmium analysis of the samples revealed that $\mathrm{Cd}$ concentration was varying from $2.31 \mu \mathrm{g} \mathrm{L}^{-1}$ to $8.96 \mu \mathrm{g} \mathrm{L}^{-1}$ in water (Mean/SD - 5.28/9.1), 0.55 $\mu \mathrm{g} \mathrm{g}^{-1}$ to $25.44 \mu \mathrm{g} \mathrm{g}^{-1}$ in soil (Mean/SD - 3.6/3.2) and $0.45 \mu \mathrm{g} \mathrm{g}^{-1}$ to $22.90 \mu \mathrm{g} \mathrm{g}^{-1}$ in sediment (Mean/SD - 8.95/9.9). Cadmium levels in soil, sediment and water samples of the study area are represented in Table 1. Cadmium resistance studies of the bacterial isolates showed that out of 164 collected isolates the majority showed low resistance $(<500 \mu \mathrm{g} / \mathrm{ml})$ and the rest showed high resistance of $>1500 \mu \mathrm{g} / \mathrm{ml}$.

Table 2. Bacterial genera found in soil, sediment and water samples from the Eloor- Edayar Industrial belt

\begin{tabular}{|c|l|l|l||}
\hline \multirow{2}{*}{$\begin{array}{r}\text { No } \\
\text { No. }\end{array}$} & \multicolumn{3}{|c|}{ Sample } \\
\cline { 2 - 4 } & Soil & Sediment & Water \\
\hline 1 & Bacillus & Kurthia & Staphylococcus \\
\hline 2 & Caryophanon & Pseudomonas & Acinetobacter \\
\hline 3 & Listeria & Bacillus & Azotobacter \\
\hline 4 & Kurthia & Enterobacter & Bacillus \\
\hline 5 & Agromyces & Escherichia & Pseudomonas \\
\hline 6 & Arthrobacter & & Xanthobacter \\
\hline 7 & Cellulomonas & & Enterobacter \\
\hline 8 & Deinococcus & & Escherichia \\
\hline 9 & Psedomonas & & Klebsiella \\
\hline 10 & Enterobacter & & Aeromonas \\
\hline 11 & & & Thiobacillus \\
\hline \hline
\end{tabular}

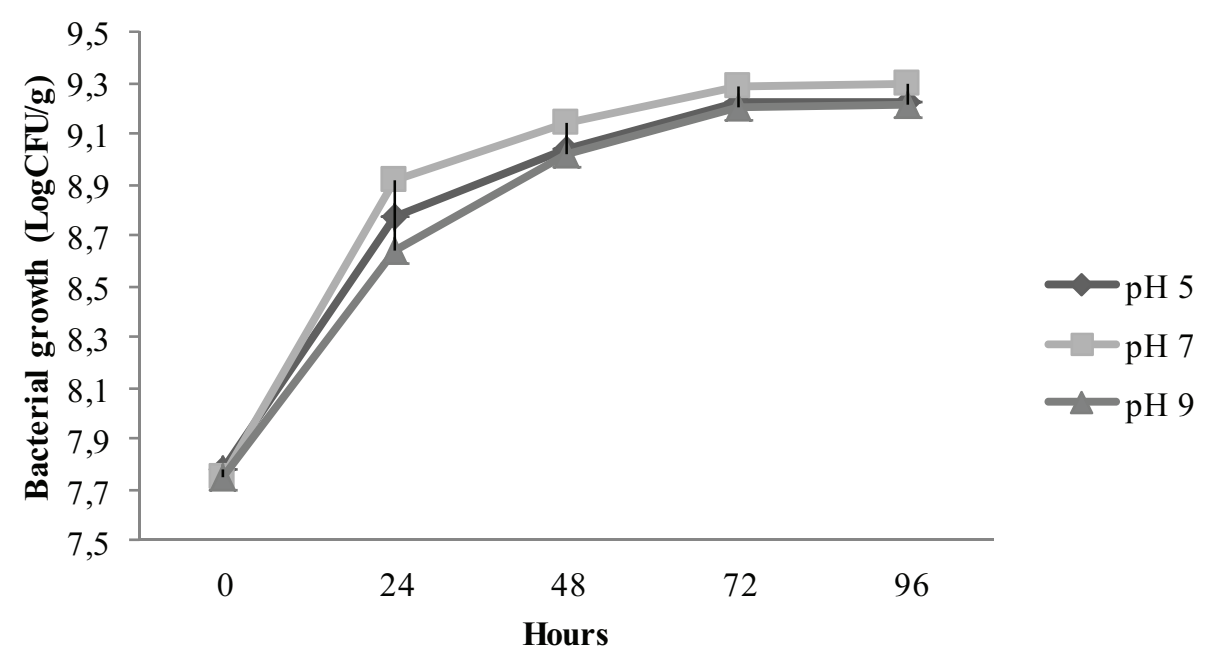

Fig. 1. Growth kinetics of Pseudomonas sp. at different $p^{H}$ with 20mg/L initial concentration of cadmium

Results of the cadmium removal study revealed that with an increase in time the biomass of selected Pseudomonas sp. increased (Fig. 1). Correspondingly, with an increase in biomass the cadmium bioaccumulation also increased. Generally, $40 \%$ of cadmium in the experimental flask decreased, while only a $5 \%$ reduction occurred in the control flasks till the end of the experiment (74 hr) (Figs 2-4) Comparatively, the cadmium removal showed higher reduction at $\mathrm{pH} 7$ (Fig. 5). Relatively, an increased removal of cadmium was observed in the first day of the experiment.

\section{Discussion}

Amounts $\left(3 \mu \mathrm{g} \mathrm{L}^{-1}\right)$ of cadmium in the water samples obtained from the selected industrial area were higher than permitted by the WHO 1993 standard. Typically, fresh water contains the level of 
cadmium below 1 microgram per liter, but the concentrations up to $10 \mu \mathrm{gL}^{-1}$ may occur on rare occasions due to the environmental disturbances such as acid rain. In the present work in water samples a 23 times higher content of cadmium was found which may be caused by the leakage of waste water from the industrial area. The cadmium level in soil of the selected industrial area was generally higher than the WHO 1993 standard value of $2.0 \mathrm{mgkg}^{-1}$. The level of cadmium in sediment far more exceeded the acceptable limit of $0.6 \mathrm{mgkg}^{-1}$. In the case of soil samples, cadmium showed the enrichment level exceeding the normally expected distribution, giving rise to concern over suitability of soil in the study area (Srinivasa et al. 2005; Yefang et al. 2006; Govil et al. 2008). High levels of cadmium were observed in several pockets, closer to the industries which specified that the source of those elements could be industrial effluents.

Cadmium resistance studies of the bacterial isolates showed that out of 164 collected isolates the majority showed low resistance $(<500 \mu \mathrm{g} / \mathrm{ml})$ and many isolates showed high resistance of $>1500 \mu \mathrm{g} / \mathrm{ml}$. High level of resistance and widespread tolerance that was found among the isolates were probably attributed to the cadmium contents in soil (AbouShanab et al. 2007). The varying level of tolerance among 164 cultures may be due to the difference in the concentration of cadmium in the environment. The site from which the samples were taken had been polluted with high level of heavy metal for many years, perhaps giving a diverse range of bacteria a chance to adapt to the environment either by convergent evolution of resistance mechanisms or by transferring the resistance genes via a plasmid. Resistance to heavy metal, including cadmium, zinc, copper, chromate, cobalt, arsenic and nickel is most often carried out by bacteria on plasmids or transposons and it has been theorized that this allows for lateral transfer in the environment (Silver 1992).

The results of heavy metal removal studies showed that with an increase in time, the biomass of the bacterial strains increased. Likewise, with an increase in the biomass, the cadmium bioaccumulation also increased. An increase in the surface area that can be due to an increase in biomass improves the adsorptive nature or increases the number of active binding sites on cell surface (Bai et al. 2002). The selected metal resistant strains showed that their growth was only slightly affected with different $\mathrm{pH}$. Therefore, it is clear that growth of our isolates is not inhibited with different $\mathrm{pH}$ and this fact makes them strong candidates for future application to metal bioremediation.

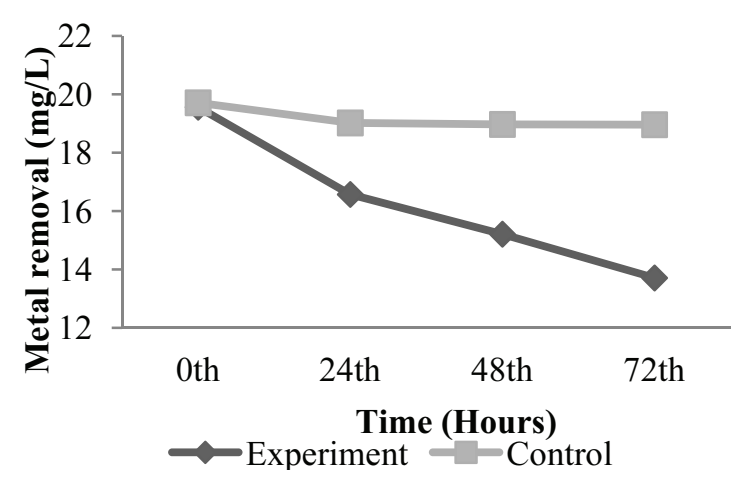

Fig. 2. Bioaccumulation of cadmium using Pseudomonas sp. at $p^{H} 9$

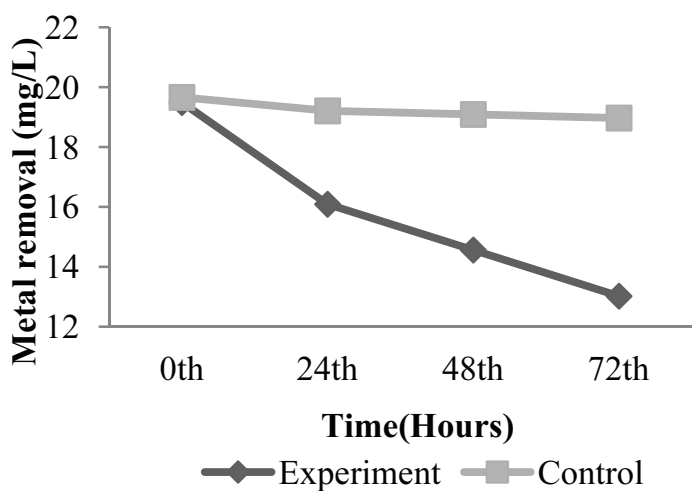

Fig. 3. Bioaccumulation of cadmium using Pseudomonas sp. at $\mathrm{pH} 7$

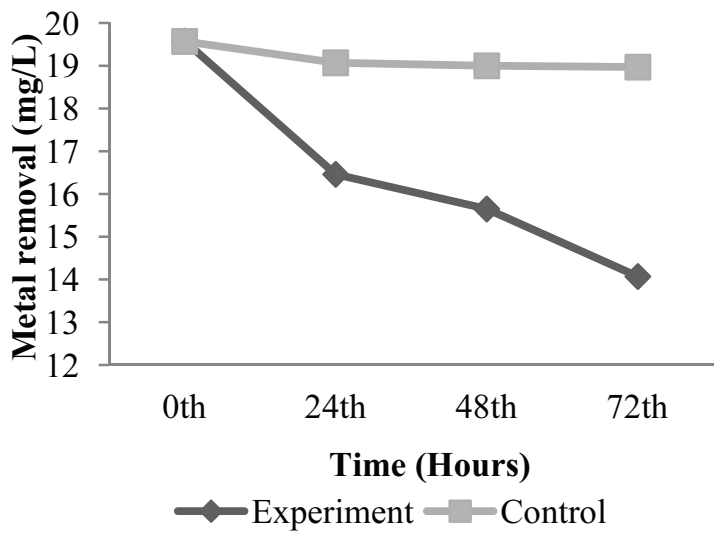

Fig. 4. Bioaccumulation of cadmium using Pseudomonas sp. at pH 5

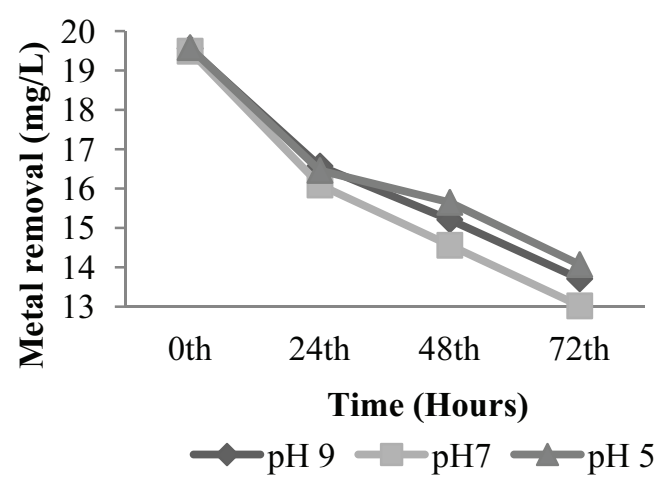

Fig. 5. Effect of $p H$ on cadmium removal using Pseudomonas sp. 
The active mode of metal accumulation by living cells is usually designated as bioaccumulation. This process is dependent on the metabolic activity of the cell referred to its intrinsic biochemical and structural properties, physiological and/or genetic adaptation, environmental modification of metal specification, availability and toxicity (Cha and Cooksey 1991). The capacity of living cells to remove metal ions from aqueous solutions is also significantly influenced by environmental growth conditions, as the temperature, $\mathrm{pH}$ and biomass concentrations (Chen and Ting 1995).

Many researchers have reported on efficiency and mechanisms of bacteria to remove different metal ions, many of their statements are comparable to the present study. Richard et al., (2002) reported that $\mathrm{Cu}^{+2}$ and $\mathrm{Pb}^{+2}$ seemed to bind to materials on their cell surface. Lead is precipitated in an insoluble form that is localized to the cell membrane or cell surface (Aiking et al. 1985; Levinson et al, 1996; Roane 1999). This could be generally explained by the fact that the negatively charged groups (carboxyl, hydroxyl and phosophryl) of the bacterial cell wall adsorb metal cations through various mechanisms such as electrostatic interaction, van der Waals forces, covalent bonding or the combination of such processes (Chojnacka et al, 2005).

As $\mathrm{pH}$ values in metal-containing water and wastewater can vary, to examine the effect of heavy metal removal the solutions of different $\mathrm{pH}$ values are to be used. In the present work, the initial $\mathrm{pH}$ has been adjusted in the range of 5, 7 and 9 before the addition of biosorbent. The medium $\mathrm{pH}$ affects solubility of metals and ionization state of the functional groups such as carboxylate, phosphate and amino ones of the cell wall. Inconsistency in the literature regarding the influence of $\mathrm{pH}$ on biosorption seems to indicate that the way $\mathrm{pH}$ would alter the adsorption of metal ions to biomass varies with both the type of adsorbents (biomass) and the type of adsorbates (metal ions). Obtained results have shown that the selected Pseudomonas $s p$. is a good bioaccumulation medium for cadmium ions and has a high adsorption yield for the treatment of wastewater containing cadmium ions. Consequently, bacteria bioaccumulation technologies are being developed and much more work in this field is to be done.

\section{References}

ABOU-SHANAB, R.A.I., BERKUM, P., ANGLE, J. S. Heavy metal resistance and genotypic analysis of metal resistance genes in gram-positive and gram-negative bacteria present in Ni-rich serpentine soil and in the rhizosphere of Alyssum murale. Chemosphere, 2007, vol. 68, $\quad$ pp. 360-367. http://dx.doi.org/10.1016/j.chemosphere.2006.12.051

AIKING, H. GOVERS, H., VANT RIET, J. Detoxification of mercury, cadmium, and lead in Klebsiella aerogenes NCTC 418 growing in continuous culture.
Applied Environmental Microbiology, 1985, Vol. 50, pp. 1262-1267.

APHA, 1998. Standard methods for Examination of Water and Waste water. $20^{\text {th }}$ ed., American Public Health Association, American Water Works Association, Water Environmental Federation, Washington, D.C.

AYRES, R.U. Toxic heavy metals: materials cycle optimization, The Proceedings of the National Academy of Sciences USA, 1992, Vol. 89, pp. 815-820. http://dx.doi.org/10.1073/pnas.89.3.815

BAI, S., ABRAHAM, R., EMILA, T. Studies on enhancement of $\mathrm{Cr}$ (VI) biosorption by chemically modified biomass of Rhizopus nigricans. Water Research, 2002, Vol. 36, pp. 1224-1236. http://dx.doi.org/10.1016/S0043-1354(01)00330-X

BOOPATHY, R. Factors limiting bioremediation technologies. Bioresource Technology, 2000, Vol. 74, pp. 63-67. http://dx.doi.org/10.1016/S0960-8524(99)00144-3

BRIERLEY, C.L., KELLY, D.P., SEAL, K.J., BEST, D.J. 1985. in: I.J. Higgyns, D.J. Best, J. Jones (Eds.), Biotechnology, Blackwell, Oxford, pp. 163-212.

BUCHANAN, R. E., GIBBONS, N. E. 1974. Bergey's manual of determinative bacteriology. (Eighth edition), The Williams and Wilkins Co., Baltimore.

CHA S. AND COOKSEYD, A. Copper resistance in Pseudomonas syringae mediated by periplasmic and outer membrane proteins. Proceedings of the National Academy of Sciences of the United States of America, 1991, Vol. 88, pp 8915-8919. http://dx.doi.org/10.1073/pnas.88.20.8915

CHEN, P., TING, Y.P. Effect of heavy metal uptake on the electrokinetic properties of Saccharomyces cerevisiae. Biotechnology letters, 1995, Vol. 17, pp. 10712. http://dx.doi.org/10.1007/BF00134205

CHOJNACKA, K., CHOJNACKI, A., GORECKA, $\mathrm{H}$. Biosorption of $\mathrm{Cr}+2, \mathrm{Cd}+2$ and $\mathrm{Cu}+2$ ions by blue green alga Spirulina sp. Kinetics, equilibrium and the mechanism of the processes. Chemosphere, 2005, Vol. 59, pp. 75-84. http://dx.doi.org/10.1016/j.chemosphere.2004.10.005

GADD, G.M. Microbial formation and transformation of organometallic and organometalloid compounds, FEMS Microbiology Reviews, 1993, Vol. 11, pp. 297-316. http://dx.doi.org/10.1111/j.1574-6976.1993.tb00003.x

GOVIL, P.K., SORLIE, J.E., MURTHY, M.N., SUJATHA, D., REDDY, G.L.N., RUDOLPH-LUND, K., KRISHNA, A.K., RAMAMOHAN, K. Soil contamination of heavy metals in the Katedan Industrial Development Area, Hyderabad, India, Environmental Monitoring and Assessment. 2008, Vol. 140, pp. 313-323. http://dx.doi.org/10.1007/s10661-007-9869-x

HOLT, J. G., KRIEG, N. R., SNEATH, P. H. A., STALEY, J. T., WILLIAMS, S. T. 1994. Bergey's Manual of Determinative Bacteriology (Ninth edition). Williams and Wilkins. London.

IRELAND- RIPERT, J., BERMOND, A., DUCAUZE, C. (1982). Determination of methyl mercury in the pressure of inorganic mercury by anodic stripping 
voltammetry. Analytica Chimica Acta, 1982, Vol. 143, pp. 249-254.

KINGSTON, H.M., WALTER, P.J., HALK, S.J., LORENTZEN, E.M., LINK, D. 1997. Environmental microwave sample preparation: Fundamentals, sample preparation, and applications, ACS professional reference book series, Washington DC.

KINGSTON, H.M., JASSIE, L.B. 1988. Safety guidelines for microwave systems in the analytical laboratory. In Kingston, H.M. and Jassie, L.B. (Eds.), Introduction to microwave acid decomposition: Theory and Practice. ACS Professional reference book series. Washington DC

LEVINSON, H. S., MAHLER, I. BLACKWELDER, P. AND HOOD, T. (1996). Lead resistance and sensitivity in Staphylococcusaureus. Microbial. Lett. 1996, Vol.. 145, pp. 421-425.

LO, J., LEE, J. Dithiocarbamate Extraction and $\mathrm{Au}(\mathrm{iii})$ Back Extraction for Determination of Mercury in Water and Biological Samples by Anodic Stripping Voltammetry, Analytical Chemistry 1994, Vol. 66, pp 1242-1248. http://dx.doi.org/10.1021/ac00080a008

LUI, G. W., TALNAGI, J. W., STROHL, W. R., PFISTER, R. M. Hexavalent chromium resistant bacteria isolated from river sediments. Applied Environmental Microbiology, 1983, Vol. 46, pp 846-854.

RARAS, A.G. Biological and biotechnological waste management in material processing, Journal of the Minerals Metals \& Materials Society, 1995, Vol. 47, pp. 56-63. http://dx.doi.org/10.1007/BF03221411

RICHARD, W. G, D. KRUMHOLZ, D., MATTHEW, S. C. AND LOUIS, S. T. Heavy metal resistance pattern of frankia strains. Applied Environmental Microbiology, 2002, Vol. 68, pp. 923-927.

RUIZ-MANRIQUEZ, A., MAGANA, P.I., LOPEZ, V., GUZMAN, R. Biosorption of $\mathrm{Cu}$ by Thiobacillus ferrooxidans, Bioprocess Engineering., 1997, Vol. 18, pp. $113-118$

SILVER, S. Plasmid-determined metal resistance mecha- nisms: range and overview. Plasmid, 1992, Vol. 27, pp. 1-3. http://dx.doi.org/10.1016/0147-619X(92)90001-Q

SRINIVASA GOWD, S., KRISHNA, A.K., GOVIL, P.K. Environmental risk assessment and remediation of soils contaminated due to waste disposal from tannery industries: a case study of Ranipet industrial area, Tamil Nadu, India, Geochim. Cosmochim. Acta, 2005, Vol. 69, pp.427.

VALLEE, B.L., AULD, D.S. Zinc coordination, function, and structure of zinc enzymes and other proteins. Biochemistry, 1990, Vol. 29, pp. 5647-5659. http://dx.doi.org/10.1021/bi00476a001

WHO 1993. Environmental Health Criteria 135 IPCS. Cadmium - Environmental Aspect.

YEFANG, S., ZHENGMIAO, X., JING, L., JIANMING, X. ZULIANG, C., RAVI, N. Assessment of toxicity of heavy metal contaminated soils by the toxicity characteristic leaching procedure, Environmental Geochemistry and Health, 2006, Vol. 28, pp. 73-78. http://dx.doi.org/10.1007/s10653-005-9014-0

Krishna M.P - M. Phil. Scholar at School of Environmental Sciences, Mahatma Gandhi University, Kottayam, Kerala.

Main research areas: Environmental Microbiology, Heavy metal removal, Bacterial Taxonomy.

Tel.: $\quad 919562587609$

E-mail: krishnatkd@gmail.com

Rinoy Varghese - research scholar at School of Environmental Sciences, Mahatma Gandhi University, Kottayam, Kerala.

Main research areas: Environmental Microbiology, Heavy metal removal, Bacterial Taxonomy, Food microbiology, Antibacterial resistance.

Tel.: $\quad 919744777401$

E-mail: renochirackal@gmail.com

Arun Babu V - research scholar at School of Environmental Sciences, Mahatma Gandhi University, Kottayam, Kerala.

Main research areas: Environmental Biotechnology, Heavy metal removal, Waste management.

Tel.: $\quad 919446463871$

E-mail: arunses@gmail.com

A.A. Mohamed Hatha - associate professor at Department of Marine Biology, Microbiology and Biochemistry, Cochin University of Science and Technology, Cochin, Kerala.

Main research areas: Environmental Microbiology, Aquatic microbiology, Probiotics, Biofilm studies, Heavy metal removal studies, Bacterial Taxonomy, Food microbiology, Antibacterial resistance, Antarctic Microbiology etc.

Tel.: $\quad 919446866050$

E-mail: mohammedhatha@gmail.com 


\title{
Kadmiu užteršto pramoninio regiono išvalymo analizė naudojant biologiškai sukauptas bakterijas Pseudomonas $S p$
}

\author{
M. P. Krishna ${ }^{1}$, Rinoy Varghese ${ }^{1}$, Arun V. Babu ${ }^{1}$, A. A. Mohamed Hatha ${ }^{2}$ \\ ${ }^{l}$ Aplinkosaugos mokykla, Mahatma Gandhi universitetas, Kottayam, Kerala. \\ ${ }^{2}$ Jüru biologijos katedra, Kochin mokslu ir technologijos universitetas, Kerala.
}

(gauta 2012 m. vasario mèn., priimta spaudai 2012 m. rugséjo mèn.)

\begin{abstract}
Atliekant tyrimą, buvo tirtas bakteriju atsparumas sunkiujų metalu poveikiui, taip pat ivvertintas biologinès akumuliacijos potencialas. Iš sunkiaisiais metalais užteršto pramoninio regiono buvo paimta dirvožemio, nuosèdų ir vandens pavyzdžių. Analizė parodė, jog kadmio $(\mathrm{Cd})$ koncentracija kito nuo $2,31 \mu \mathrm{g} \mathrm{L}-1$ iki $8,96 \mu \mathrm{g} \mathrm{L}-1$ vandenyje, nuo $0,55 \mu \mathrm{g}$ g-1 iki $25,44 \mu \mathrm{g} \mathrm{g}-1$ dirvožemyje ir $0,45 \mu \mathrm{g} \mathrm{g}-1$ iki $22,90 \mu \mathrm{g} \mathrm{g}-1$ nuosèdose. Bakteriju atsparumo kadmiui tyrimas parodè, kad iš 164 surinktų bakterijų rūšių dauguma buvo neatsparios $(<500 \mu \mathrm{g} / \mathrm{ml})$, tik nedidelè dalis buvo labai atsparios $(>1500 \mu \mathrm{g} / \mathrm{ml})$. 10 bakterijų rǔšių buvo aptiktos dirvožemio pavyzdyje, 11 - vandenyje ir 5 - nuosèdu bandinyje. Bacillus, Pseudomonas ir Enterobacter buvo rastos dirvožemio, vandens ir nuosèdų bandiniuose. Kadmio pašalinimo tyrimai atskleidè, jog padidèjus Pseudomonas sp. biologinei masei padidèjo metalų atranka, taip pat padidėjus biologinès masès kiekiui daugiau buvo sukaupta kadmio. Santykinai daugiau kadmio buvo pašalinta pirmają eksperimento dieną, nes apie 40 proc. esančio bandinyje kadmio buvo ịsisavinta. Paskutinę bandymo dieną $(74 \mathrm{~h})$ metalo buvo ịsisavinta tik 5 proc. Didesnis akumuliacinis potencialas buvo esant optimaliam $\mathrm{pH}$ (apie 7). Atliktas tyrimas parode, jog bakterijos labai geba kaupti kadmi ir yra tinkamos teritorijoms, užterštoms sunkiaisiais metalais, valyti.
\end{abstract}

